\title{
Benign Melanocytic Skin Nevus
}

National Cancer Institute

\section{Source}

National Cancer Institute. Benign Melanocytic Skin Nevus. NCI Thesaurus. Code C7571.

A benign, circumscribed proliferation of melanocytes in the skin. Variants include the Spitz nevus, halo nevus, blue nevus, and balloon cell nevus. 